International Journal of Engineering \& Technology, $7(2.29)(2018)$ 1058-1062
International Journal of Engineering \& Technology
SPC
Website: www.sciencepubco.com/index.php/IJET
Research paper

\title{
Competency Model of Indonesian Construction Laborers in Malaysia
}

\author{
Fadillah Ismail $^{1 *}$, Intan Sazrina Saimy², Rosman Md. Yusoff ${ }^{3}$, Anis Yusal Yusoff ${ }^{4}$, \\ Chan Shiau Wei ${ }^{5}$, Umi Kartini Rashid ${ }^{6}$ \\ ${ }^{1,5,6}$ Faculty Of Technology Management and Business, Universiti Tun Hussein Onn Malaysia \\ Faculty of Engineering and Life Sciences, Universiti Selangor \\ Centre For General Studies and Co-Curricular, Universiti Tun Hussein Onn Malaysia \\ Malaysian Institute of Integrity \\ *Corresponding Author E-Mail: Fadillah@Uthm.Edu.My
}

\begin{abstract}
Quality of human resources is a significant factor to improve high productivity performance of an organization or industry. The quality of human resources can be indicated through competence, skills, ability and other specific characteristics of employee to build a teamwork within organization. Competency-Based on training emphasizes what an employee can do more than how much they know. Hence, through a mixed research method using explanatory approach, this study aims to build a model of Indonesian labor competency based on the competence of 300 Indonesian construction laborers in Malaysia. This model emphasizes four criteria of competency which are communication, skills, interpersonal, and attitude. The finding showed that Indonesian labor force is competent in communication, interpersonal, and attitude. However, Indonesian labor force is seen to be incompetent in criterion skills and still needs training to improve their skills to be in line with the industry needs
\end{abstract}

Keywords: Competency Model; Construction Sector; Indonesian Labor Force

\section{Introduction}

Together with the world development today, human resource development has been given the priority by most countries. This is because, the human capital has been identified as the main drive towards development and success of many organization even the country itself. Emphasis towards the aspect of human resource development can be seen through the transition of development pattern and the countries' focus that was based on the industries in the 90s era towards a country based on economic knowledge. This is based on human resource that was identified as the main component towards success and knowledge based economic development.

Some of the factors that contributes to the success of human resource development are preparation and skills training according to the task of each individual. With the employer playing an important role in the training preparation, a learning module was built based on the competency model according to each individual's tasks and skills. The competency model is a guideline for reference for any individuals on their tasks. According to [1] competency acts as guide on the behaviors or process recommended in the competency model.

According to Noe [2], competency is an individual ability for employees to do their job with the expected result. Competency is also knowledge, skills, attitude, values or individual characteristics. The competency model acts to identify the competency that is needed for each knowledge, skills, attitude, values or individual characteristics that are the base of competency.
Competency model can be an effective approach and interesting to build the capacity and professional performance $[3,4]$. Competency model is a holistic approach that can estimate an individual's competence and to those who needed persuasion. Furthermore, the competency model is aspiring of originality and confidence. Therefore, the model functions as a progress for those with high ambition and to improve their professional practice. Through individual perspectives, the competency model is a strong work development tool [3]. For short, the competency model contributes to a major professional development progress and helps in determine the work practice and work competency.

According to Dubois and Rothwell [1], the competency model functions to explain the attitude needed of a worker and to identify the appropriate competency based on his job scope. Each competency model usually will have one to five indicators of attitude.

Meanwhile, Noe [2] stated that the competency model was developed to enhance the work performance of a worker. Many organization faces problems on the performance management system developed that failed to reach an agreement by both parties; employer and the employees on the results and criteria that can be used to assess the employees.

Additionally, the function of competency model developed was to guide the shape and characteristics of an individual for an excellent work performance. This model would also explain in detail each element trait in the organization context or culture and individual tasks.

The purpose of competency is to determine the behavioral standards needed by a worker to carry out tasks given by an organization or to improve the training program for the future [5]. By using the competency, simple organization can easily determine the 
worker is ready to be moved to a higher or horizontal level [6]. If the worker is not ready, the competency can be used to identify the needed training.

Nevertheless, Norfakhriah [7], contended that a more holistic approach can be achieve by using the competency model. First, it can be revised and identify what is needed to answer a question. Second, the competency approach can be as a base or template in work hiring, work development and human resource and job promotion. Third, using the competency model, the needed capacity can be determined by the labors in achieving their work target.

In addition, competency model can identify the quality and characteristics of excellent workers and the medium performance worker. Competency model can also predict the training needs precisely therefore reducing the ineffective training. It can describe the work performance and clue for the long term. It can overall increase the job satisfaction. Lastly, the competency model acts as an information to human resource in the process of job promotion, workers recognition, workers acknowledgement, employment and more.

\section{Literature Review}

\subsection{Competency Concept}

The human capital was defined as an accelerator for long term effectiveness that cannot be replaced and sustainability in any organization [8]. Its importance was growing together with the global economic development. Porvazník and Ljudvigová [9] asserted that the secret for high prestige and job satisfaction are, human needs to have control of our own life, to learn and create something new and be better. We are talking about skills, knowledge, attitude, loyalty or involvement. This quality is called competent. The word competency originated from the Latin word that was translated as "people that has the right to judge" or "people that has the right to talk".

Competency is a scientific term used every day. With many underlying word, there can be seen little semantics that uses the word ability, effective, competent, and skills. Competency can be related to individual, social groups or institution, when they own or obtain the prerequisites to achieve their development goals and meeting important demands.

According to Skorková [8], various concepts were translated but can be summarized as the following:

-Competency as the power and responsibility. A worker has the right to do specific activities: maneuver jurisdiction and its effect. Therefore, it refers to what has been given to human

- Competency as the ability of an individual to perform specific activities - quality, skills, and ability to do it efficiently. This idea emphasizes on the intrinsic human quality that enables its achievement[10-13].

To identify the efficiency in a community brought forward the creation of competency model for certain characteristics. Competency model can be used in many human resource development intakes of officers, remuneration process, design training and development program. It is the key tool in assessing the workers, career planning and talent management.

\subsection{Competency Model [3]}

Competency model is a mechanism to identify competence in the conceptual framework that enables people in an organization understood, discuss and use competency [14]. Although, according to Kumar et al. [15], the competency model intends to focus on the competency standards that is needed for specific jobs. Competency involves knowledge, skills, ability, value, motivation and trusts to for someone to do a successful job.

In this research, the competency model was adapted with [3] that is a competency model of combined knowledge, skills and characteristics that are needed in an organization and used as a tool to choose, train and develop, asses and replacement planning.
Intellectual Skills relates to each job scope of each worker. The elements are creative, problem analysis, planning, technical expertise and others.

\section{ii. Communication Skill}

Communication aspects consists of speech, information delivery and negotiation to achieve a certain task.

\section{iii. Personal Skill}

Personal skill is the attitude and character shown by an individual during work. Among the elements are integrity, independence, accountability and others.

\section{iv. Interpersonal Skill}

Interpersonal skills are skills in understanding a situation and other co-workers, customers and higher management. The elements in interpersonal skills are such consultancy, sensitivity, persuasion and others.

\section{v. Leadership Skill}

Leadership skill are skills to other individuals such as other coworkers, customers and higher management. The elements in this element are motivation, to develop and individual control.

\section{vi. Orientation Skill}

Orientation skill are skills that shows the superior attitude and high commitment without violating the human aspects.

Through the six criteria of the competency skill, it has enabled a systematic guideline to explain on the knowledge, skills and standard values that the Indonesian labors need to have. It directly lists the elements of knowledge, skills attitude for prospective construction labors to have. To carry out an efficient work, the competency model is used to measure the competency level of Indonesian labors and the results used as a guideline to identify the training needs.

\section{Methodology}

This research uses a survey method by using a mixed method by combining two phases of data collection; quantitative and qualitative. This explanatory research collects the data from many types of explanation. Quantitative data collection was used as the main method in this research. Meanwhile, qualitative analysis was used to explain further the questionnaires and results of significant, insignificant or deviation [16].

Sampling is a research strategy whereby the researcher can gain information about a population from certain individuals of the population itself [17]. This research aims to collect data and collect information on specification together with explanation on the construction work sector in Malaysia as well as Indonesia and its differences between the two countries. This will eventually will assess the training needs by the Indonesian labors. This research was implemented in all states in Johor.

This research has 300 quantitative respondents of Indonesian labors that are working in Malaysia and residing in the state of Johor Respondents was chosen according to stratified sampling according to districts.

This research uses a survey method and questionnaire as the research instrument. According to Saunders [18], questionnaire enables all data to be collected, analyzed and compare easily. Each question in the questionnaire was built based on the literature and approved by experts. There are 24 questions divided into three sections with section A: respondents' background; section B: construction labors specification; and section C: explanation on construction work sector.

The questionnaires were collected and processed based on certain codes by using the Statistical Package for Social Science [SPSS] version 22 . The data were analyzed using statistical methods such as descriptive and inferential statistics. The score of section $\mathrm{C}$ was measured by using five points Likert scale. Strongly disagree was given the value of 1 , disagree the value of 2 , not sure the value of 3 , agree the value of 4 , and strongly agree the value of 5 .

\section{i. Intellectual Skill}




\section{Results and Findings}

Table 1: Labors Demography

\begin{tabular}{|c|c|c|}
\hline Category & Frequency & Percentage [\%] \\
\hline \multicolumn{3}{|l|}{ Gender } \\
\hline Male & 263 & 87.7 \\
\hline Female & 37 & 12.3 \\
\hline \multicolumn{3}{|l|}{ Breed } \\
\hline Java & 220 & 73.3 \\
\hline Sunda & 2 & 0.7 \\
\hline Malay & 29 & 9.7 \\
\hline Madura & 7 & 2.3 \\
\hline Bugis & 5 & 1.7 \\
\hline Batak & 1 & 0.3 \\
\hline Batawi & 3 & 1.0 \\
\hline Others* & 33 & 11.0 \\
\hline \multicolumn{3}{|l|}{ Religion } \\
\hline Islam & 287 & 95.7 \\
\hline Buddhist & 2 & 0.7 \\
\hline Cristian & 10 & 3.3 \\
\hline No answer & 1 & 0.3 \\
\hline \multicolumn{3}{|l|}{ Age } \\
\hline$<18$ years & 2 & 0.7 \\
\hline $18-22$ years & 23 & 7.7 \\
\hline 23-27 years & 63 & 21.0 \\
\hline 28-32 years & 77 & 25.7 \\
\hline 33-37 years & 51 & 17.0 \\
\hline $38-42$ years & 37 & 12.3 \\
\hline 43-47 years & 31 & 10.3 \\
\hline 48 years and above & 16 & 5.3 \\
\hline \multicolumn{3}{|l|}{ Income } \\
\hline$<\mathrm{RM} 1000$ & 74 & 24.7 \\
\hline RM 1001-1500 & 189 & 63.0 \\
\hline RM 1501-RM 2000 & 21 & 7.0 \\
\hline RM 2001-RM 2500 & 12 & 4.0 \\
\hline RM 2501-RM 3000 & 3 & 1.0 \\
\hline RM 3001-RM 3500 & 1 & 0.3 \\
\hline \multicolumn{3}{|l|}{ Type of Work } \\
\hline Iron & 37 & 12.3 \\
\hline Rocks & 87 & 29.0 \\
\hline Woods & 93 & 31.0 \\
\hline Concrete [beton] & 23 & 7.7 \\
\hline Acian/Finishing/Plaster/Tile & 30 & 10.0 \\
\hline $\begin{array}{l}\text { Infrastructure [Drains/ } \\
\text { Roads/ Roofing/ Bridge] }\end{array}$ & 9 & 3.0 \\
\hline Others $* *$ & 21 & 7.0 \\
\hline \multicolumn{3}{|l|}{ District } \\
\hline Johor Bahru & 248 & 82.7 \\
\hline Batu Pahat & 24 & 8.0 \\
\hline Muar & 6 & 2.0 \\
\hline Pontian & 5 & 1.7 \\
\hline Kulai & 12 & 4.0 \\
\hline Mersing & 5 & 1.7 \\
\hline \multicolumn{3}{|l|}{ Education } \\
\hline Not formally educated & 5 & 1.7 \\
\hline Primary School [SD] & 96 & 32.0 \\
\hline $\begin{array}{l}\text { Lower Secondary School } \\
\text { [SMP] }\end{array}$ & 123 & 41.0 \\
\hline $\begin{array}{l}\text { Higher Secondary School } \\
\text { [SMA] }\end{array}$ & 75 & 25.0 \\
\hline S3 & 1 & 0.3 \\
\hline
\end{tabular}

*Other types of breed include Flores, Flores NTT, Sasak/ Lombok, dan Seri Laku.

**other type of work includes drainage, roofing, landscape, paint, and wiring

This part would elaborate on the background of the respondents There were 300 respondents involved in this research. From the 300 respondents, 263 people [87.7\%] respondents are male and only 37 people [12.3\%] respondents are female. Most of the respondents, 220 people [73.3\%] are Java and 29 people [9.7\%] respondents are Malay. Less than $10 \%$ of the respondents are Sunda, Madura, Bugis, Batak, and Batawi. Nevertheless, 33 people [11.0\%] respondents are Flores, Flores NTT, Sasak / Lombok and Seri Laku. Overall, 287 people [95.7\%] are Islam, 10 people [3.3\%] respondents are Christians, and 2 people [0.7\%] respond- ents are Buddhist. Only some of the respondents did not answer this question. In the sense of age, many respondents that is 77 people [25.7\%] respondents are in the age between 28 to 32 years, followed by the 23 to 27 years old [21\%] respondents. Only 2 people [0.7\%] respondents that was under the age of 18 years old. More than half of the respondents, that is 189 people [63.0\%] earns between RM 1001 to RM1500, 74 people [24.7\%] respondents earns below RM1000 and 21 people [7.0\%] respondents earns between RM1501 to RM2000. Only some of the respondents [0.3\%] earns between RM3001 to RM3500. Most of the Indonesian respondents work in the wood finishing section. From 300 respondents involved, 93 people are in the wood section followed by the rock section with 87 people [29.0\%] and iron with 37 people [12.3\%] respondents. Acian/ finishing/ plaster/ tile are of 30 people [10.0\%] respondents, concretes [beton] as many as 23 people [7.7\%] respondents, other infrastructure such as drainage, roads, roofing, and bridges are 9 people [3.0\%] respondents. There are about 21 people [7.0\%] respondents that do other type of work such as roofing, landscaping, painting and wiring.

More than $80 \%$ respondents which is 248 people of Indonesian labours work in Johor Bahru, 24 people [8.0\%] respondents in Batu Pahat, 12 people [4.0\%] respondents work in Kulai, 6 people [2.0\%] respondents in Muar, and 5 people [1.7\%] respondents each in Pontian and Mersing. Almost half of the respondents that is 123 people [41.0\%] respondents had the lower high school certificate, and only 96 people [32.0\%] are until the primary school level. Only 5 people [1.7\%] respondents that has never had any formal education.

Results showed respondents in this research covers the Indonesian labours with various background, skills, different level of wages and education.

Table 2: Communication Competency

\begin{tabular}{|l|l|}
\hline Competency & Frequency \\
\hline Language Proficiency & \\
\hline Unable & \\
\hline Able & $10[3.3 \%]$ \\
\hline Skilful & $231[91.6 \%]$ \\
\hline English & $59[19.7 \%]$ \\
\hline Unable & \\
\hline Able & $275[91.6 \%]$ \\
\hline Skilful & $25[8.3 \%]$ \\
\hline Chinese & - \\
\hline Unable & \\
\hline Able & $300[100.0 \%]$ \\
\hline Skilful & - \\
\hline
\end{tabular}

This competency model assesses the labours competency through four criteria; communication, skills, interpersonal and attitude. Results in Table 2 above shows the communication skills of Indonesian construction labours in Malaysia. The skills were measured according to their language proficiency in speaking Malay, English and Chinese. Results shows majority of the Indonesian labours are capable in speaking Malay. Even, 59 respondents are skilful in speaking Malay. Malay language is the country's official language and medium language between ethnicities and race in the country. However, only 25 people [8.3\%] of Indonesian labours can speak English. It was also found, not any of the respondents can speak Chinese.

Table 3: Skill Competency [3M]

\begin{tabular}{|l|l|}
\hline \multicolumn{2}{|c|}{ Table 3: Skill Competency [3M] } \\
\hline Competency & Frequency \\
\hline 3M [Writing, Reading, Calculate] \\
\hline Writing & \\
\hline Able & $280[93.3 \%]$ \\
\hline Unable & $20[6.7 \%]$ \\
\hline Reading & $259[86.3 \%]$ \\
\hline Able & $41[13.7 \%]$ \\
\hline Unable & \\
\hline Calculate & $277[92.3 \%]$ \\
\hline Able & $23[7.7 \%]$ \\
\hline Unable &
\end{tabular}


Competency skills are measured by the $3 \mathrm{M}$ [writing, reading and calculate] skills in using work materials, skills in handling modern technologies work equipment, and the skills in lifting, cutting, bending and measuring. Table 3 shows the $3 \mathrm{M}$ competency skills of Indonesian labours. 3M Competency skills was measured by their writing, reading and calculating skills. Majority of the Indonesian labours, 90 percent of the respondents have $3 \mathrm{M}$ skills. Less than 15 percent of the Indonesia workforce does not have the $3 \mathrm{M}$ skills.

Table 4: Skill Competency [Work Material]

\begin{tabular}{|l|l|l|}
\hline Competency & \multicolumn{2}{|c|}{ Frequency } \\
\hline Use of Work Material & Capable & Incapable \\
\hline Rock & $140[46.7 \%]$ & $160[53.3 \%]$ \\
\hline Iron & $95[31.7 \%]$ & $205[68.3 \%]$ \\
\hline Wood & $160[53.3 \%]$ & $140[46.7 \%]$ \\
\hline Concrete & $153[51.0 \%]$ & $147[49.0 \%]$ \\
\hline Finishing & $117[39.0 \%]$ & $183[61.0 \%]$ \\
\hline
\end{tabular}

Table 4 shows the usage skills of work material by the Indonesian labours. Results show that many of the Indonesian labours were not skilful in using the work materials. Only the wood usages and concrete that has the skilful Indonesian labours with more than 50 percent.

Table 5: Skill Competency [Handling Modern Equipment

\begin{tabular}{|l|l|l|}
\hline Competency & \multicolumn{2}{|c|}{ Frequency } \\
\hline Handling Modern Equipment & Capable & Incapable \\
\hline Rock & $125[41.7 \%]$ & $175[58.3 \%]$ \\
\hline Iron & $104[34.7 \%]$ & $196[65.3 \%]$ \\
\hline Wood & $122[40.7 \%]$ & $178[59.3 \%]$ \\
\hline Concrete & $130[43.3 \%]$ & $170[56.7 \%]$ \\
\hline Finishing & $102[34.0 \%]$ & $198[66.0 \%]$ \\
\hline Others & $115[38.3 \%]$ & $185[61.7 \%]$ \\
\hline
\end{tabular}

Table 5 above shows the competency skills in handling modern equipment. Findings showed more than half of the respondent are unskilled in handling modern work equipment that involved rocks, iron, wood, concrete, finishing, and other construction infrastructure. This shows that the Indonesian labours are incompetent in handling modern equipment.

Table6: Skill Competency [Lifts, Cut, Bend, Measure]

\begin{tabular}{|l|l|l|}
\hline Competency & \multicolumn{2}{|c|}{ Frequency } \\
\hline $\begin{array}{l}\text { Lifting, Cutting, Bending, Measur- } \\
\text { ing }\end{array}$ & Capable & Incapable \\
\hline Rock & $152[50.7 \%]$ & $148[49.3 \%]$ \\
\hline Iron & $105[35.0 \%]$ & $195[65.0 \%]$ \\
\hline Wood & $129[43.0 \%]$ & $171[57.0 \%]$ \\
\hline Concrete & $131[43.7 \%]$ & $169[56.3 \%]$ \\
\hline Finishing & $123[41.0 \%]$ & $177[59.0 \%]$ \\
\hline
\end{tabular}

Competency work skills of Indonesian labours in lifting, cutting, bending and measuring materials such as rocks, iron, and wood, concrete and finishing are still low. Less than 50 percent of the 300 people Indonesian labours who are the respondents in this research have the necessary skills.

The third competency measured in this model is the interpersonal competency. Interpersonal Competency are skills in understanding a situation and other co-workers, customers or higher management There are three items measured through this competency that is creative thinking, unafraid of heights and not wasteful.

Table 7: Interpersonal Competency

\begin{tabular}{|l|l|l|}
\hline Competency & \multicolumn{2}{|c|}{ Frequency } \\
\hline INTERPERSONAL & Capable & Incapable \\
\hline Creative thinking & $192[64.0 \%]$ & $108[36.0 \%]$ \\
\hline Unafraid of Heights & $230[76.6 \%]$ & $70[23.3 \%]$ \\
\hline Not Wasteful: & & \\
\hline Rocks & $212[70.7 \%]$ & $88[29.3 \%]$ \\
\hline Iron & $183[61.0 \%]$ & $117[39.0 \%]$ \\
\hline Wood & $195[65.0 \%]$ & $105[35.0 \%]$ \\
\hline Concrete & $206[68.7 \%]$ & $94[31.3 \%]$ \\
\hline Finishing & $186[62.0 \%]$ & $114[38.0 \%]$ \\
\hline Others & $201[67.0 \%]$ & $99[33.0 \%]$ \\
\hline
\end{tabular}

Table 7 display the competency of Indonesian work skills in the interpersonal skills. Results showed the Indonesian has high competency level in these criteria when all items have high frequencies, more than 50 percent achieved creative thinking, unafraid of heights, and not wasteful. Not wasteful item was measured by the type of work they do such as usage of rock, iron, and wood, concrete, finishing and other construction infrastructure.

Table 8: Attitude Competency

\begin{tabular}{|l|l|l|}
\hline Competency & \multicolumn{2}{|c|}{ Frequency } \\
\hline Attitude & Capable & Incapable \\
\hline Employer/ Organisation & $227[75.7 \%]$ & $73[24.3 \%]$ \\
\hline Responsible and work committed & $233[77.7 \%]$ & $67[22.3 \%]$ \\
\hline Willing to work overtime & $225[75.0 \%]$ & $75[25.0 \%]$ \\
\hline Obeys superior & & \\
\hline Willing to learn: & $206[68.7 \%]$ & $94[31.3 \%]$ \\
\hline Rock & $186[62.0 \%]$ & $114[38.0 \%]$ \\
\hline Iron & $203[67.7 \%]$ & $97[32.3 \%]$ \\
\hline Wood & $233[77.7 \%]$ & $67[22.3 \%]$ \\
\hline Concrete & $192[64.0 \%]$ & $108[36.0 \%]$ \\
\hline Finishing & $201[67.0 \%]$ & $99[33.0 \%]$ \\
\hline Others & \multicolumn{2}{|c|}{} \\
\hline Asks if not clear: & $194[64.7 \%]$ & $106[35.3 \%]$ \\
\hline Rock & $179[59.7 \%]$ & $121[40.3 \%]$ \\
\hline Iron & $200[66.7 \%]$ & $100[33.3 \%]$ \\
\hline Wood & $208[69.3 \%]$ & $92[30.7 \%]$ \\
\hline Concrete & $192[64.0 \%]$ & $108[36.0 \%]$ \\
\hline Finishing & $210[70.0 \%]$ & $90[30.0 \%]$ \\
\hline Others & $222[74.0 \%]$ & $78[26.0 \%]$ \\
\hline Co-Workers & $229[76.3 \%]$ & $71[23.7 \%]$ \\
\hline Motivating co-workers & $236[78.7 \%]$ & $64[21.3 \%]$ \\
\hline Knowledge sharing & $217[72.3 \%]$ & $83[27.7 \%]$ \\
\hline Guide & 121 ] & \\
\hline Good teamwork & & \\
\hline Atitude comp & & \\
\hline
\end{tabular}

Attitude competency in this model measures the attitude of Indonesia labours towards their employers or organisation also towards their co-workers. It shows their attitude at work. Results showed that they are capable to be responsible and committed towards the tasks given, obeys their superiors and always ready to learn new skills that proved to be helpful in their job. They were also willing to ask whenever there are any unclear assignments to prevent mishaps. The Indonesian labours are competent in having the ability to influence other individuals such as co-workers and the management. Over 70 percent of the respondents inferred that they are capable to motivate other co-workers and guide in any type of work and having good teamwork. They are willing to share knowledge with co-workers in any type of task.

Figure 1 below shows the training competency model developed from this research

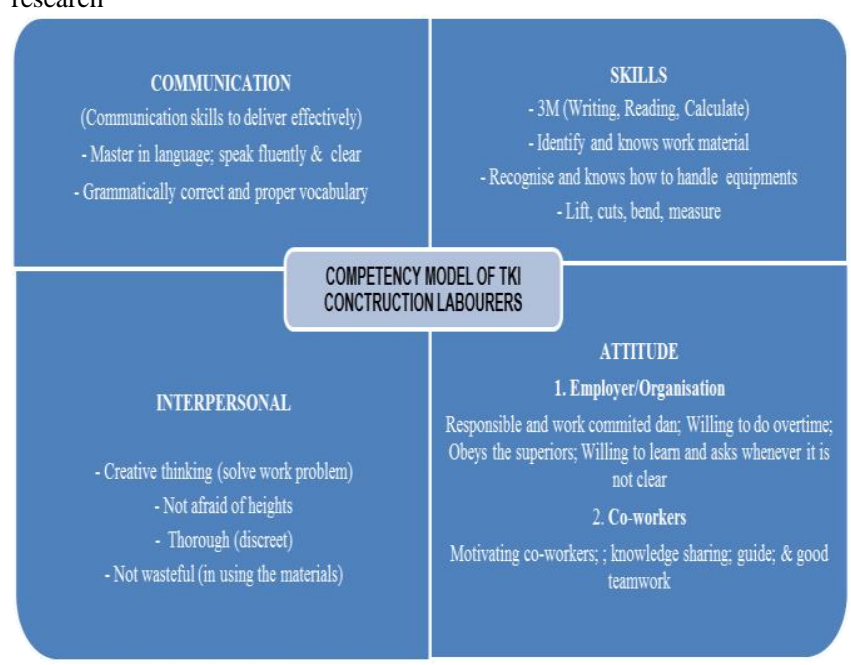

Fig. 1: Training competency model

Fig.1: Competency Model of TKI Construction Labourers 


\section{Conclusion}

The construction workers competency model highlights four criteria that are communication, skills, interpersonal, and attitude. Through analysis done, it can be concluded that the Indonesia labors have the competency to communicate especially in Malay language. They were able to understand instructions and communicate with other co-workers in Malay language. Results also showed that the Indonesian labors are competent in the interpersonal and attitude criteria whereby they are seen to be able to understand a situation, other co-workers, customers and higher management. They were able to understand a situation where they need to be creative and able to work in high altitude places especially in the construction industry. The Indonesian labors were seen able to influence other individuals by giving motivation, guidance, and work in groups and sharing knowledge. Nevertheless, the Indonesian labors was incompetent in skills as they have yet to master in the materials usage, modern equipment and also unskilled in lifting, cutting, bending and measuring. Therefore, the Indonesian labors needed to be given trainings and skills according to job scope. Skill training is seen as compulsory for their own ability to enable labors to be successful in their work and satisfy the employers.

\section{References}

[1] Dubois D, Rothwell W. Competency-Based Human Resource Management: Discover a New System for Unleashing the Productive Power of Exemplary Performers: Nicholas Brealey Publishing; 2004.

[2] Noe RA, Peacock M. Employee training and development. 2002.

[3] Sanghi S. The handbook of competency mapping: understanding, designing and implementing competency models in organizations: SAGE Publications India; 2016.

[4] Stevens GW. A critical review of the science and practice of competency modeling. Human Resource Development Review. 2013;12[1]:86-107.

[5] Parshionikar SU, Willian-True S, Fout GS, Robbins DE, Seys SA Cassady JD, et al. Waterborne outbreak of gastroenteritis associated with a norovirus. Applied and Environmental Microbiology. 2003;69[9]:5263-8.

[6] Cooper K. Effective competency modeling \& reporting: a step-bystep guide for improving individual \& organizational performance: AMACOM Div American Mgmt Assn; 2000.

[7] Norfakhriah CO. Compliment responses among Malay undergraduates/Norfakhriah Che Othman: University of Malaya; 2017.

[8] Skorková Z. Competency models in public sector. Procedia-Social and Behavioral Sciences. 2016;230:226-34.

[9] Porvazník J, Ljudvigová I. General theory of systems, cybernetics and evaluation of human competence by solving present crisis problems of civilisation. Procedia-Social and Behavioral Sciences. 2016;230:112-20.

[10] AAA. Commentary: SEC Auditor Independence Requirements. Accounting Horizons. 2001;15[4]:373-86.

[11] Rasli AM, Norhalim N, Kowang TO, Qureshi MI. Applying managerial competencies to overcome business constraints and create values evidence from small technology-based firms in Malaysia. Journal of Management Info. 2014;3[1]:99-121.

[12]Bibi S, Iftikhar M, Qureshi MI, Khan K, Zaman K. Exploring the relationship among professional competence, job satisfaction and Career development confidence of chefs: an empirical research in Pakistan. 2013.

[13] Qureshi MI, Zaman K, Shah IA. Relationship between rewards and employee's performance in the cement industry in Pakistan. Journal of international academic research. 2010;10[2]:19-29.

[14] Marrelli AF. An introduction to competency analysis and modeling. Performance Improvement. 1998;37[5]:8-17.

[15] Kumar Khanna V, Gupta R. Comparative study of the impact of competency-based training on 5 "S" and TQM: a case study. International Journal of Quality \& Reliability Management. 2014;31[3]:238-60.

[16] Creswell JW, Clark VLP. Designing and conducting mixed methods research. 2007.
[17] Cohen AD, Macaro E. Language learner strategies: Thirty years of research and practice 2007.

[18] Saunders MN. Research methods for business students, 5/e: Pearson Education India; 2011 